Participative Journal

Jurnal Pengabdian Pada Masyarakat

Vol. 01, No. 01, April 2021

Homepage journal: https://jurnal.jurmat.com/index.php/pi

\title{
MANAJEMEN MUTU TERPADU PONDOK PESANTREN RAUDLATUL MUSLIMIN NW KAYANGAN BATU LAYAR LOMBOK BARAT
}

\author{
Fathurrahman Muhtar*1 \\ *Affiliasi: Universitas Islam Negeri Mataram
}

\begin{abstract}
This is an activity to focus on developing a madrasa community supported by UIN Mataram which is to develop Madrasah Aliyah Nahdlatul Wathan Raudlatul Muslim Kayangan Sandik's management capabilities. Coaching method for madrasah development plan with Trainer of Trainer(TOT) strategy material for five pillars of Total Quality Management (TQM). The results will provide leaders, teachers, employees and stakeholders with a clear understanding of the concept of the five TQM pillars. The understanding is then transferred into the development plan for madrasah.
\end{abstract}

Keywords: madrasah, management, TQM, TOT

Journal Info:

Received, 07 Februari 2021 | Revised, 15 Maret 2021 | Published, 12 April 2021

\footnotetext{
${ }^{1}$ Corresponden to the author: Prodi Tadris Matematika, UIN Mataram.

Jl. Gajah Mada Jempong, Indonesia (83116), email address : fathurrahmanmuhtar@uinmataram.ac.id
} 


\begin{abstract}
Abstrak
Kegiatan ini merupakan kegiatan pendampingan pengembangan masyarakat madrasah binaan UIN Mataram yang bertujuan untuk mengembangan kemampuan manajemen Madrasah Aliyah Nahdlatul Wathan Raudlatul Muslimin Kayangan Sandik Lombok Barat. Metode pembinaan dengan Trainer of Trainer (TOT) materi strategi penyusunan rencana pengembangan madrasah dengan konsep 5 pilar TQM. Hasil dari pelatihan ini dapat memberikan pemahaman kepada kepala sekolah, guru, staf dan stakeholder tentang konsep 5 Pilar TQM. Pemahaman tersebut kemudian dituangkan ke dalam Penyusunan Rencana Pengembangan madrasah.
\end{abstract}

Kata Kunci: madrasah, management, TQM, TOT

\title{
Pendahuluan
}

Perkembangan ilmu pengetahuan dan teknologi telah membawa perubahan di hampir semua aspek kehidupan manusia dimana berbagai permasalahan hanya dapat dipecahkan kecuali dengan upaya penguasaan dan peningkatan ilmu pengetahuan dan teknologi. Selain manfaat bagi kehidupan manusia di satu sisi perubahan tersebut juga telah membawa manusia ke dalam era persaingan global yang semakin ketat. Agar mampu berperan dalam persaingan global, maka sebagai bangsa kita perlu terus mengembangkan dan meningkatkan kualitas sumber daya manusianya. Oleh karena itu, peningkatan kualitas sumber daya manusia merupakan kenyataan yang harus dilakukan secara terencana, terarah, intensif, efektif dan efisien dalam proses pembangunan, kalau tidak ingin bangsa ini kalah bersaing dalam menjalani era globalisasi tersebut.

Peningkatan kualitas sumber daya manusia akan terlaksana apabila lembaga pendidikan seperti sekolah dan madrasah mampu menjadi lembaga yang bermutu. Dewasa ini, salah satu tantangan penting yang dihadapi sekolah/madrasah adalah bagaimana mengelola sebuah mutu. ${ }^{2}$ Bagi setiap institusi, mutu adalah agenda utama dan meningkatnya mutu merupakan tugas yang paling penting, sebab saat ini terdapat masalah dalam system pendidikan. Lulusan SLTA/MA tidak siap memenuhi kebutuhan masyarakat. Masalah ini berakibat bagi masyarakat. Para siswa yang tidak siap menjadi warga Negara yang bertanggungjawab dan produktif itu, akhirnya hanya jadi beban masyarakat. Para siswa seperti itu adalah produk system pendidikan yang tidak terfokus pada mutu, yang akhirnya memberatkan anggaran kesejahteraan social. Dewasa ini upaya 
peningkatan mutu pendidikan terus dilakukan oleh berbagai pihak dan pendekatan. Upaya- upaya tersebut dilandasi suatu kesadaran betapa pentingnya peranan pendidikan dalam pengembangan sumber daya manusia dan pengembangan watak bangsa (Nation Character Building) untuk kemajuan masyarakat dan bangsa.

Kebutuhan dan harapan masyarakat (community need and wants) akan mutu pelayanan pendidikan yang baik tampaknya menjadi factor pemicu utama inovasi manajemen pendidikan. Keputusan institusional atau institutional decisions yang dibuat oleh kepala sekolah dan staf untuk meningkatkan mutu pelayanan internal (di dalam lembaga sekolah) dan eksternal (hubungan sekolah dan masyarakat) akan sangat mempengaruhi proses pembuatan keputusan inivatif dalam bidang manajemen pendidikan. Kegiatan pendidikan dan pengajaran disekolah hanya akan berjalan baik jika ditunjang oleh manajemen pendidikan yang memadai. ${ }^{3}$

Manajemen pendidikan yang memadai lambat laun dapat mengangkat harkat dan martabat suatu bangsa, sebab martabat suatu bangsa sangat ditentukan oleh kualitas pendidikannya. Dalam konteks bangsa Indonesia, peningkatan mutu pendidikan merupakan sasaran pembangunan di bidang pendidikan nasional dan merupakan bagian integral dari upaya peningkatan kualitas manusia Indonesia secara menyeluruh. ${ }^{4}$

Salah satu penyebab mutu pendidikan di Indonesia rendah karena system pendidikan yang bersifat sentralistis. ${ }^{5}$ Oleh sebab itu, untuk meningkatkan mutu pendidikan pemerintah membuat kebijakan otonomi daerah. Seiring dengan era otonomi dan proses demokrasi serta desentralisasi, pengembangan kualitas menuntut partisipasi dan pemberdayaan seluruh komponen pendidikan dan penerapan konsep pendidikan sebagai suatu sistem. Peningkatan mutu pendidikan dalam kerangka otonomi daerah merubah arah dan paradigma penyelenggaraan yang dulunya dengan pola sentralisasi ke arah pendidikan yang desentralisasi. ${ }^{6}$

Salah satu langkah strategis dalam meningkatkan mutu madrasah yaitu penyusunan pengembangan rencana sekolah/madrasah (RPS) dengan mengacu kepada 5 pilar Manajemen Mutu Terpadu (Total Quality Manajemen) ${ }^{7}$. Setiap sekolah/madrasah pada umumnya telah memiliki visi, misi dan tujuan yang menjadi acuan dalam penyelenggaraan pendidikan di sekolah/madrasah. Berbagai program yang dikembangkan tersebut harus relevan dengan visi dan misi madrasah serta sebagai bentuk pejabaran yang lebih rinci, terukur, dan feasible untuk dilaksanakan di madrasah. Pengembangan program sekolah/madrasah hendaknya dilakukan melalui penahapan yang sistematis dengan langkah-langkah yang dapat dipertanggungjawabkan, baik secara akademik, yuridis maupun social. Pengembangan program sekolah juga harus mempertimbangkan potensi dan kemampuan sekolah, sejauhmana kekuatan 
sekolah/madrasah dan lingkungan mendukung keterlaksanaan program, dan apakah terdapat ancaman atau hambatan dalam pelaksanaan nantinya ${ }^{8}$

Penyusunan Rencana pengembangan madrasah tersebut merupakan langkah awal bagi madrasah untuk meningkatkan mutu pelayanan kepada masyarakat. Dalam Manajemen Mutu Terpadu sekolah/madrasah dipahami sebagai Unit Layanan Jasa, yakni pelayanan pembelajaran. Sebagai unit layanan jasa, maka yang dilayani sekolah (pelanggan sekolah ) adalah: 1) Pelanggan internal : guru, pustakawan, laboran, teknisi dan tenaga administrasi, 2) Pelanggan eksternal terdiri atas : pelanggan primer (siswa), pelanggan sekunder (orang tua, pemerintah dan masyarakat), pelanggan tertier (pemakai/penerima lulusan baik diperguruan tinggi maupun dunia usaha). Berikut Gambar 5 Pilar Manajemen Mutu Pendidikan. ${ }^{9}$

Seperti digambarkan dalam model dibawah ini, criteria untuk sekolah bermutu terpadu ditandai dengan "pilar mutu" untuk pendidikan. Pilar mutu ini bersifat universal. Dapat diterapkan untuk setiap organisasi pendidikan mulai dari kegiatan diruang kelas sampai perawatan bangunan. $^{10}$

Kegiatan Pengabdian Madrasah Binaan di laksanakan di Pondok Pesantren Raudlatul Muslimin NW Kayangan yang terdiri dari Pendidikan Raudlatul Atfal dengan jumlah siswa 34 orang, Madrasah Ibtidaiyah dengan jumlah siswa 50 orang, Madrasah Tsanawiyah dengan jumlah siswa 80 orang dan Madrasah Aliyah berjumlah 75 orang. Jumlah Tenaga Pendidik terdiri dari Pendidikan Raudlatul Atfal berjumlah 10 orang, Madrasah Ibtidaiyah terdiri dari 8 orang guru, Madrasah Tsanawiyah terdiri dari 12 orang guru, Madrasah Aliyah terdiri dari 20 orang guru. Pondok pesantren tersebut berada dibawah Yayasan Pendidikan Raudlatul Muslimin NW Kayangan. Luas lokasi berdirinya pondok pesantren $956 \mathrm{~m} 2$. Sebagian guru sudah disertifikasi.

MMTP akan sukses diterapkan pada lembaga pendidikan jika manajer pendidikan melakukan SAL (Seharusnya yang Anda Lakukan), yaitu :

a. Pahami: filosofi, visi, misi, aksi, kebutuhan pelanggan dan keunikan karyawan.

b. Ciptakan: proses yang efisiens, budaya kerja yang kondusif, dan tim kerja yang solid

c. Galakkan: pencatatan data, usaha perbaikan, dan semangat kerja

d. Kembangkan: diri sendiri, bawahan dan rekanan:

e. Dapatkan: kesamaan persepsi, komitmen atasan, teman selevel dan bawahan:

f. Terapkan: gaya kepemimpinan partisipatif. ${ }^{11}$

\section{Metode}

participative journal : Jurnal Pengabdian Pada Masyarakat | h. 4 
Metode kegiatan yang digunakan dalam kegiatan pelatihan ini lebih menyerupai bentuk ToT (Traine of Trainer) dengan beberapa teknik prosedur sebagai berikut :

Penyuluhan dan pelatihan, metode ini dimaksudkan untuk menyajikan materi tentang pendidikan berbasis mutu terpadu. Tanya jawab, untuk memberikan kesempatan bertanya kepada peserta penyuluhan dan pelatihan terhadap materi atau hal-hal lain yang belum dipahami. Tugas, dimaksudkan untuk mengetahui sejauhmana hasil penyuluhan dan pelatihan ini dapat dipahami oleh peserta. Diskusi, untuk membahas rencana tindaklanjut penyebarluasan di sekolah masingmasing. Adapun pendekatan yang digunakan bersifat 'persuasif-edukatif', dengan beberapa metode antara lain: ceramah, diskusi, demonstrasi, dan praktek/latihan. Selanjutnya, proses analisis kebutuhan pelatihan (training need analysis). Pada tahap pertama pelaksana memerlukan fase penilaian yang ditandai dengan satu kegatan utama yaitu analsis kebutuhan pelatihan. Analisis kebutuhan pelatihan dilakukan melalui sebuah proses tanya jawab (asking question getting answers). Pertanyaan diajukan kepada setiap tenaga pendidikan dan kependidikan dan kemudian membuat verifikasi dan dokumentasi tentang berbagai masalah dimana akhirnya kebutuhan pelatihan dapat diketahui untuk memecahkan masalah tersebut. Untuk memastikan keberhasilan pelatihan dapat dilakukan melalui evaluasi. Secara sistimatik manajemen pelatihan meliputi tahap perencanaan yaitu training need analysis, tahap implementasi dan tahap evaluasi. Tahap terakhir merupakan titik kritis dalam setiap kegiatan karena acap kali diabaikan sementara fungsinya sangat vital untuk memastikan bahwa pelatihan yang telah dilakukan berhasil mencapai tujuan ataukah justru sebaliknya.

\section{Hasil Dan Pembahasan}

Hasil kegiatan pendampingan yang dilakukan yaitu melakukan kegiatan pelatihan dan pembinaan mutu madrasah yang ada di Pondok Pesantren Raudlatul Muslimin NW Kayangan dalam bentuk pelatihan dengan pengayaan materi Total Quality Manajeman. Adapun MateriMateri yang akan menjadi pembahasan dalam pelatihan ini adalah Rangkaian perencanaan mewujudkan mutu pendidikan: Desain Visi dan Misi, Analisa Pasar, Analisis SWOT, perencanaan operasi, kebijakan dan perencanaan mutu, biaya mutu, evaluasi. Kegiatan ini diikuti oleh 40 orang peserta yang terdiri dari guru madrasah Ibtidaiyah, Tsanawiyah dan Aliyah. 


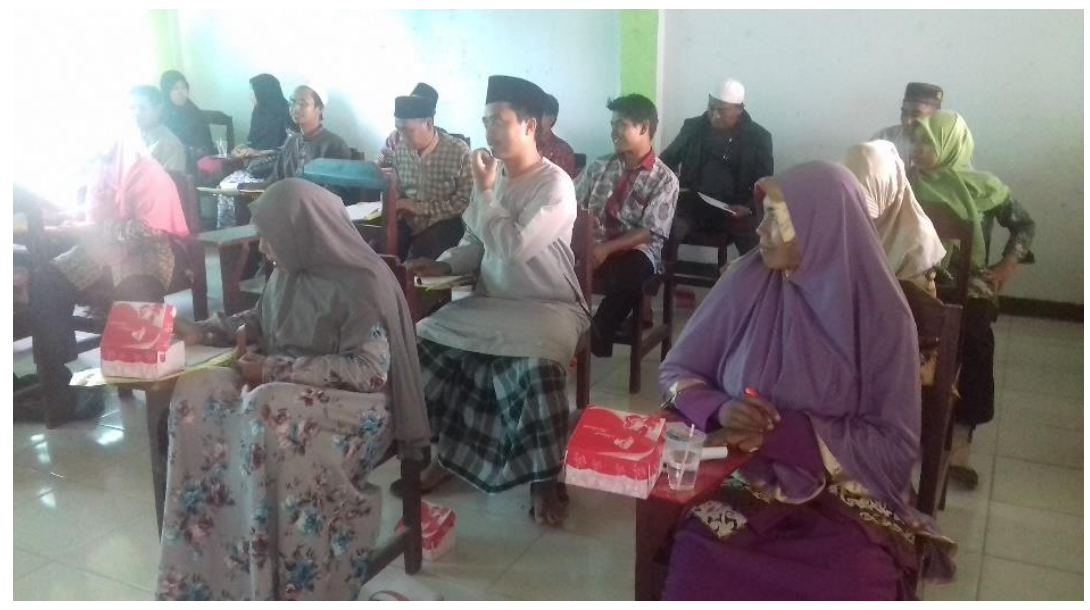

\section{Gambar 1:}

Peserta Madrasah Binaan

Adapun pembicara pada kegiatan ini adalah Lembaga Pengabdian Masyarakat dan Dewan Pendidikan Propinsi Nusa Tenggara Barat.

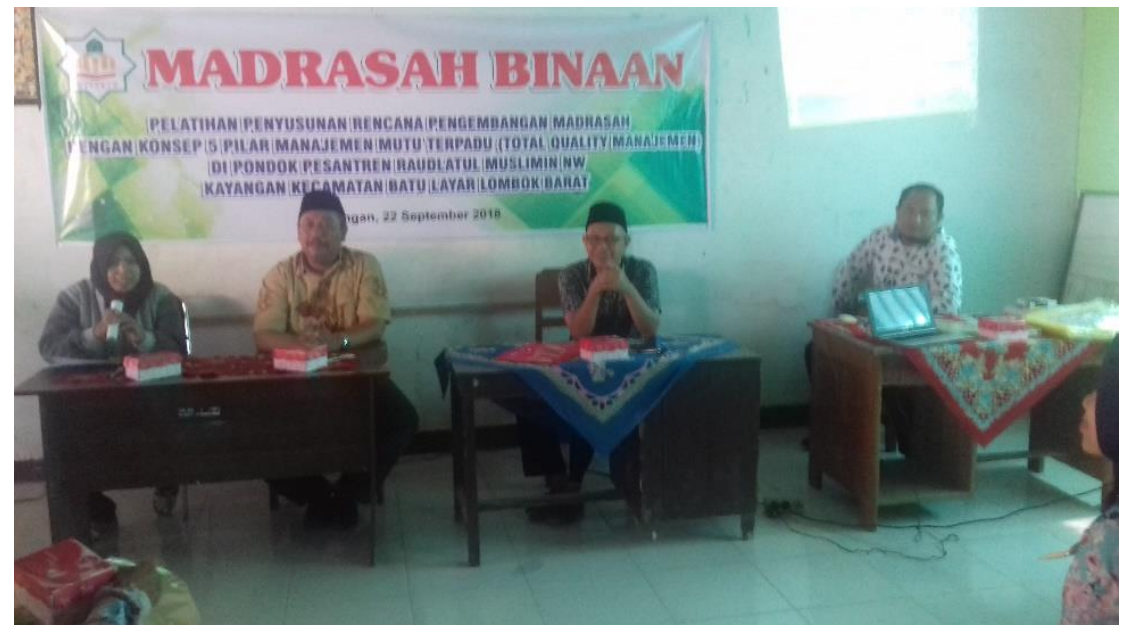

Gambar 2:

Narasumber dari LPM dan Dewan Pendidikan Propinsi NTB

Setelah diadakan kegiatan pelatihan ini pihak madrasah memiliki pemahaman tentang berbagai macam pemahaman yang terkait dengan Rencana Pengembangan Madrasah yang meliputi :

1. Pentingnya tujuan Rencana Pengembangan Madrasah, yaitu sebagai berikut:

a. Mendukung koordinasi antarpelaku pendidikan;

b. Menjamin terciptanya integrasi, sinkronisasi, dan sinergi baik antara madrasah dengan kementerian agama kabupaten, wilayah dan pusat 
c. Menjamin keterkaitan dan konsistensi antara perencanaan, penganggaran, pelaksanaan, dan pengawasan;

d. Mengoptimalkan partisipasi masyarakat; dan menjamin tercapainya penggunaan sumberdaya secara efisien, efektif, berkeadilan, dan berkelanjutan.

2. Memahami esensi RPM Jangka Panjang, Menengah (Strategis), dan Tahunan.

a. RPS Jangka Panjang adalah dokumen perencanaan sekolah untuk periode 20 (dua puluh) tahun;

b. RPS Jangka Menengah (Rencana Strategis) adalah dokumen perencanaan sekolah untuk periode 5 (lima) tahun;

c. RPS Tahunan adalah dokumen perencanaan sekolah untuk periode 1 (satu) tahun.

\section{Peningkatan Kualitas Madrasah}

Kualitas pendidikan Madrasah meliputi input, proses, dan output, dengan catatan bahwa output sangat ditentukan oleh proses, dan proses sangat dipengaruhi oleh tingkat kesiapan input. Contoh-contoh perencanaan kualitas misalnya, pengembangan pendidik dan tenaga kependidikan (guru, kepala sekolah, konselor, pustakawan, laboran, dsb.), pengembangan komite sekolah, rasio, (siswa/guru, siswa/kelas, siswa/ sekolah), pengembangan bahan ajar, pengembangan model pembelajaran (pembelajaran tuntas, pembelajaran dengan melakukan, pembelajaran kontekstual, pembelajaran kooperatif, dsb.), pengembangan komite sekolah, dsb. peningkatan kualitas siswa (UAN, UAS, keterampilan kejuruan, kesenian, olahraga, karya ilmiah, keagamaan, ke-disiplinan, karakter, budi-pekerti, dsb.)

\section{Peningkatan Efisiensi}

Efisiensi merujuk pada hasil yang maksimal dengan biaya yang wajar. Efisiensi dapat diklasifikasikan menjadi dua yaitu efisiensi internal dan efisiensi eksternal. Efisiensi internal merujuk kepada hubungan antara output sekolah (pencapaian prestasi belajar) dan input (sumberdaya) yang digunakan untuk memroses/ menghasilkan output sekolah. Efisiensi eksternal merujuk kepada hubungan antara biaya yang digunakan untuk menghasilkan tamatan dan keuntungan kumulatif (individual, sosial, ekonomik dan non-ekonomik) yang didapat setelah kurun waktu yang panjang diluar sekolah. Contoh-contoh perencanaan peningkatan efisiensi misalnya: peningkatan angka kelulusan, rasio keluaran/masukan, angka kenaikan kelas/transisi, penurunan angka mengulang, angka putus sekolah, dan peningkatan angka kehadiran. 


\section{Peningkatan Relevansi.}

Relevansi merujuk kepada kesesuaian hasil pendidikan dengan kebutuhan (needs), baik kebutuhan peserta didik, kebutuhan keluarga, dan kebutuhan pembangunan yang meliputi berbagai sektor dan sub-sektor. Contoh-contoh perencanaan relevansi misalnya; program keterampilan kejuruan/ kewirausahaan/usaha kecil bagi siswa- siswa yang tidak melanjutkan, kurikulum muatan lokal, pendidikan kecakapan hidup khususnya untuk mencari nafkah, dan lain sebagainya.

\section{Pengembangan Kapasitas Madrasah.}

Pengembangan kapasitas sekolah adalah upaya-upaya yang dilakukan secara sistematik untuk menyiapkan kapasitas sumberdaya sekolah (sumberdaya manusia dan sumberdaya selebihnya), pengem-bangan kelembagaan sekolah, dan pengembangan sistem sekolah agar mampu dan sanggup menjalankan tugas pokok dan fungsinya dalam kerangka untuk menghasilkan output yang diharapkan.

Di samping pemahaman di atas pihak madrasah dapat menyusun beberapa rencana yang meliputi : 1) Rencana Pengembangan Madrasah. 2) Rencana Strategis Madrasah yang meliputi: Rencana Pengembangan Madrasah

a) Melakukan analisis lingkungan strate-gis sekolah

b) Melakukan analisis situasi untuk mengetahui status situasi pendidikan Madrasah saat ini (IPM)

c) Memformulasikan pendidikan yang di-harapkan di masa mendatang

d) Mencari kesenjangan antara butir $2 \& 3$

e) Menyusun rencana strategis

f) Menyusun rencana tahunan

g) Melaksanakan rencana tahunan

h) Memonitor dan mengevaluasi.

\section{Rencana Strategis Madrasah}

a) Analisis situasi pendidikan sekolah saat ini

b) Analisis situasi pendidikan sekolah yang diharapkan 5 tahun kedepan (visi, misi, dan tujuan yang mencakup pemerataan, mutu, relevansi, efisiensi, kapasitas)

c) Kesenjangan antara situasi pendidikan sekolah saat ini dan yang diharapkan 5 tahun kedepan 
d) Kebijakan dan program-program strategis untuk mencapai situasi pendidikan sekolah yang diharapkan 5 tahun kedepan

e) Strategi pelaksanaan

f) Milestone (output apa \& kapan)

g) Rencana biaya (besar, alokasi, dan sumber dana)

h) Rencana pemantauan dan evaluasi.

Format Rencana Tahunan Madrasah (Alternatif I)

a) Analisis situasi pendidikan madrasah tahun ini

b) Analisis situasi pendidikan Madrasah tahun depan (yang diharapkan)

c) Kesenjangan antara pendidikan madrasah tahun ini dan pendidikan tahun depan (tantangan/loncatan).

d) Program-program untuk mengurangi kesenjangan atau untuk menghadapi tantangan/loncatan

e) Tonggak-tonggak kunci keberhasilan (milestones)

f) Rencana biaya (besar dana, alokasi, sumber dana)

g) Rencana pelaksanaan program

h) Rencana pemantauan dan evaluasi

i) Jadwal pelaksanaan program

j) Penanggungjawab program/kegiatan

Format Rencana Tahunan Madrasah (Alternatif II : SWOT)

a) Analisis situasi pendidikan sekolah tahun ini

b) Analisis situasi pendidikan sekolah tahun depan (yang diharapkan)

c) Kesenjangan antara situasi pendidikan sekolah tahun ini dan tahun depan (tantangan/loncatan)

d) Tujuan tahunan/sasaran berdasarkan hasil kesenjangan/tantangan

e) Urusan-urusan sekolah yang perlu dilibatkan untuk mencapai setiap sasaran dan yang masih perlu diteliti tingkat kesiapannya

f) Analisis SWOT (mengenali tingkat kesiapan masing-masing urusan sekolah melalui analisis SWOT)

g) Langkah-langkah pemecahan persoalan, yaitu mengubah ketidaksiapan menjadi kesiapan urusan sekolah. 
h) Rencana dan program sekolah berdasarkan hasil langkah-langkah pemecahan persoalan

i) Tonggak-tonggak kunci keberhasilan (milestones)

j) Rencana biaya (besar, alokasi, dan sumber dana)

k) Rencana pelaksanaan program

l) Rencana pemantauan dan evaluasi

m) Jadwal pelaksanaan program

n) Penanggungjawab program/kegiatan.

Disamping itu pula, dilakukan pendampingan dalam penyusunan Rencana Pengembangan Madrasah berdasarkan TQM. Dari dampingan tersebut telah dirumuskan Rencana Induk Pengembangan Madrasah (RIPM) dan Strategi Pengembangan Pondok Pesantren Raudlatul Muslimin NW Kayangan.

\section{Kesimpulan}

Hasil dari pelatihan ini dapat meningkatkan beberapa pengetahuan yang terkait dengan total quality manajemen yaitu sebagai berikut :

1. Meningkatnya kemampuan manajerial guru dan kepala Madrasah dalam kegiatan perencanaan, yang lebih sesuai dengan potensi sumber daya yang ada di lingkungan serta aspirasi masyarakat.

2. Meningkatnya peluang partisipasi dalam skala dan muatan yang lebih luas kepada guru madrasah dan pegawai dalam mengelola madrasah.

3. Berkembangnya kepemimpinan yang dapat mengakomodasi kepentingan warga madrasah serta menjadi tauladan bagi warga madrasah.

4. Tersusunnya sistem perencanaan pengembangan madrasah dengan baik.

\section{Ucapan Terima Kasih}

Ucapan terimakasih yang mendalam kepada LP2M UIN Mataram yang sudah mendukung terselenggaranya kegiatan madrasah binaan ini, terutama Ibu Rina yang sudah hadir mewakili LP2M untuk memberikan kata sambutan dalam kegiatan ini. Terimakasih pula kepada ketua Pondok Pesantren Raudlatul Muslimin NW Kayangan Ustadz Najmurrizal, M.Ag., yang telah menyediakan tempat untuk penyelenggaraan kegiatan ini. 


\section{Footnote}

1) Dalam konteks pendidikan, pengertian mutu mengacu pada masukan, proses, luaran, dan dampaknya. Mutu masukan dapat dilihat dari beberapa sisi. Pertama, kondisi baik atau tidaknya masukan sumber daya manusia, seperti kepala sekolah, guru, labiran, staf tata usaha, dan siswa. Kedua, memenuhi atau tidaknya criteria masukan material berupa alat peraga, buku-buku, kurikulum, prasarana, sarana berupa perangkat lunak, seperti peraturan, struktur organisasi, deskripsi kerja dan struktur organisasi. Keempat, mutu masukan yang bersifat harapan dan kebutuhan, seperti visi, motivasi, ketekunan dan cita-cita. Sudarman Danim, Visi Baru Manajemen Sekolah (Jakarta: Bumi Aksara, 2008), hal. 53

2) Sudarman Danim, Visi Baru Manajemen Sekolah (Jakarta: Bumi Aksara, 2008), hal. 61

3) E. Mulyasa, Manajemen Berbasis Sekolah, Konsep, Strategi, dan Implementasi, (Bandung : PT Remaja Rosdakarya, 2005), hal. 31

4) Menurut Mastuhu system pendidikan nasional dikelola secara sentralistis, berlaku di seluruh pelosok tanah air. Tujuan pendidikan, materi ajar, metode pembelajaran, buku ajar, tanaga pendidikan, baik siswa, guru maupun karyawan, mengenai persyaratan penerimaannya, tata cara kerja, bahkan pakaian dan jenjang kenaikan pangkatnya, juga penilaian hasil pendidikan dan seterusnya diatur oleh pemerintah pusat di Jakarta dan berlaku untuk semua sekolah diseluruh pelosok tanah air. Padahal tuntutan globalisasi adalah desentralisasi, otonom, dan beragam, sesuai dengan kebutuhan daerah masing-masing. Mastuhu, Menata Ulang Pemikiran Sistem Pendidikan Nasional abad 21 (Yogyakarta: Safira Insania Press, 2004), hal. 32

5) H.A.R.Tilaar, Manajemen Pendidikan Nasional, Kajian Pendidikan Masa Depan (Bandung: PT.Remaja Rosdakarya, 2004), hal.31

6) Manajemen Mutu Terpadu yang diterjemahkan dari Total Quality Management (TQM) atau disebut pula Pengelolaan Mutu Total (PMT) adalah suatu pendekatan mutu pendidikan melalui peningkatan mutu komponen terkait. M. Jusuf Hanafiah, dkk (1994:4) mendefinisikan Pengelolaan Mutu Total (PMT) adalah suatu pendekatan yang sistematis, praktis, dan strategis dalam menyelenggarakan suatu organisasi, yang mengutamakan kepentingan pelanggan. pendekatan ini bertujuan untuk meningkatkan dan mengendalikan mutu. Sedang yang dimaksud dengan Pengeloaan Mutu Total (PMT) Pendidikan tinggi (bisa pula sekolah) adalah cara mengelola lembaga pendidikan berdasarkan filosofi bahwa meningkatkan mutu harus diadakan dan dilakukan oleh semua unsur lembaga sejak dini secara terpadu berkesinambungan sehingga pendidikan sebagai jasa yang berupa proses pembudayaan sesuai dengan dan bahkan melebihi kebutuhan para pelanggan baik masa kini maupun yang akan datang.

7) Rohiat, Manajemen Sekolah, Teori Dasar dan Praktik (Bandung: Refika Aditama, 2010), hal.83

8) MMT menurut Fandy Tjiptono dan Anastasia Diana ialah suatu pendekatan dalam usaha memaksimalkan daya saing melalui perbaikan terus menerus atas jasa, manusia, produk dan lingkungan. MMT sebuah konsep yang berupaya melaksanakan system manajemen mutu kelas dunia. MMTP menurut West Burnham ialah semua fungsi dari organisasi sekolah kedalam falsafah holistis yang dibangun berdasarkan konsep mutu, kerja tim, produktivitas dan prestasi serta kepuasaan pelanggan. MMTP menurut Sallis ialah menciptakan budaya mutu dimana tujuan setiap anggota ingin menyenangkan pelanggannya, dan dimana struktur organisasinya mengizinkan untuk mereka berbuat seperti itu. Definisi mengenai MMTP mencakup dua komponen yakni apa dan bagaimana menjalankan MMTP. Dalam MMTP pelanggan adalah yang berkuasa atau sebagai raja yang 
harus dilayani sebaik-baiknya. Lihat .Husaini Usman, Manajemen, Teori Praktik dan riset Pendidikan (Jakarta: Bumi Aksara, 2008), hal. 530

9) Jerome S. Arcaro, Pendidikan Berbasis Mutu (Yogyakarta: Pustaka Pelajar, 2007), hal. 14

10) Husaini Usman, Manajemen, Teori Praktik dan riset Pendidikan (Jakarta: Bumi Aksara, 2008), hal. 530

11) Jamal Ma'ruf Asmani, Tips Praktis Membangun dan Mengolah Administrasi Sekolah (Yogyakarta: Diva Press, 2011), hal. 222

\section{Daftar Pustaka}

Asmani, Jamal Ma'ruf, Tips Praktis Membangun dan Mengolah Administrasi Sekolah, Yogyakarta:

Diva Press, 2011

Baharuddin dan Umiarso, Kepemimpinan Pendidikan Islam, Yogyakarta: Ar-Ruzz Media, 2012. Danim, Sudarman, Visi Baru Manajemen Sekolah, Jakarta: Bumi Aksara, 2008

E. Mulyasa, Manajemen Berbasis Sekolah, Konsep, Strategi, dan Implementasi, Bandung : PT Remaja Rosdakarya, 2005

Engkoswara dan Aan Komariah, Administrasi Pendidikan, Bandung: AlFabeta, 2012 H.A.R.Tilaar, Manajemen Pendidikan Nasional, Kajian Pendidikan Masa Depan, Bandung: PT.Remaja Rosdakarya, 2004

Jerome S. Arcaro, Pendidikan Berbasis Mutu, Yogyakarta: Pustaka Pelajar, 2007 Mastuhu, Menata Ulang Pemikiran Sistem Pendidikan Nasional abad 21, Yogyakarta: Safira Insania Press, 2004

Nawawi, Hadari, Manajemen Strategik Organisasi Non profit Bidang Pemerintahan Dengan Ilustrasi di Bidang Pendidikan, Yogyakarta: Gadjah Mada University, 2003

Rohiat, Manajemen Sekolah, Teori Dasar dan Praktik, Bandung: Refika Aditama, 2010 Usman, Husaini, Manajemen, Teori Praktik dan riset Pendidikan, Jakarta: Bumi Aksara, 2008 Nasution. 2005, Manajemen Mutu Terpadu (Total Quality Management). Bogor: Ghalia Indonesia.

Tjiptono, Fandy, Strategi Pemasaran. Yogyakarta: Andi Offset, 1995

Tjiptono, Fandy, Total Quality Service. Yogyakarta: Andi Offset, 2003 Gaspersz, Vincent. 2001. Total Quality Management. Jakarta: Gramedia Pustaka Utama, 2001 Simamora, Henry. 2012. Akuntansi Manajemen. Jakarta: Star Gate Publisher, 2012 Ibrahim. TQM Total Quality Management - Panduan Untuk Menghadapi Persaingan Global. Jakarta: Djambatan, 2000

Hansen dan Mowen, Akuntansi Manajerial, Buku 1 Edisi 8. Jakarta: Salemba Empat, 2009 